\title{
Association of Nonalcoholic Fatty Liver Disease (NAFLD) with Peripheral Diabetic Polyneuropathy: A Systematic Review and Meta-Analysis
}

\author{
Carla Greco ${ }^{1,2, * \mathbb{D}}$, Fabio Nascimbeni ${ }^{3} \mathbb{D}$, Francesca Carubbi ${ }^{3,4}{ }^{\mathbb{D}}$, Pietro Andreone ${ }^{3,4} \mathbb{D}$, Manuela Simoni ${ }^{1,2} \mathbb{D}$ \\ and Daniele Santi ${ }^{1,2}$
}

\section{check for} updates

Citation: Greco, C.; Nascimbeni, F.; Carubbi, F.; Andreone, P.; Simoni, M.; Santi, D. Association of Nonalcoholic Fatty Liver Disease (NAFLD) with Peripheral Diabetic Polyneuropathy: A Systematic Review and Meta-Analysis. J. Clin. Med. 2021, 10, 4466. https://doi.org/10.3390/ jcm10194466

Academic Editor: Chandana B. Herath

Received: 25 August 2021

Accepted: 24 September 2021

Published: 28 September 2021

Publisher's Note: MDPI stays neutral with regard to jurisdictional claims in published maps and institutional affiliations.

Copyright: (c) 2021 by the authors. Licensee MDPI, Basel, Switzerland. This article is an open access article distributed under the terms and conditions of the Creative Commons Attribution (CC BY) license (https:/ / creativecommons.org/licenses/by/ $4.0 /)$.
1 Unit of Endocrinology, Department of Biomedical, Metabolic and Neural Sciences, University of Modena and Reggio Emilia, 42121 Modena, Italy; manuela.simoni@unimore.it (M.S.); daniele.santi@unimore.it (D.S.)

2 Unit of Endocrinology, Department of Medical Specialties, Azienda Ospedaliero-Universitaria of Modena, Ospedale Civile di Baggiovara, 41125 Modena, Italy

3 Division of Internal Medicine and Metabolism, Department of Internal Medicine, Azienda Ospedaliero-Universitaria of Modena, Ospedale Civile di Baggiovara, 41125 Modena, Italy; fabio.nascimbeni@libero.it (F.N.); francesca.carubbi@unimore.it (F.C.); pietro.andreone@unimore.it (P.A.)

4 Unit of Internal and Metabolic Medicine, Department of Biomedical, Metabolic and Neural Sciences, University of Modena and Reggio Emilia, 42121 Modena, Italy

* Correspondence: carlagreco@unimore.it; Tel.: +39-059-396-1804; Fax: +39-059-396-1323

Abstract: Aims. The relationship between nonalcoholic fatty liver disease (NAFLD) and diabetic polyneuropathy (DPN) has been demonstrated in many studies, although results were conflicting. This meta-analysis aims to summarize available data and to estimate the DPN risk among NAFLD patients. Materials and methods. We performed a comprehensive literature review until 4 June 2021. Clinical trials analyzing the association between NAFLD and DPN were included. Results. Thirteen studies (9614 participants) were included. DPN prevalence was significantly higher in patients with NALFD, compared to patients without NAFLD (OR (95\%CI) $2.48(1.42-4.34), p=0.001$; I2 96\%). This finding was confirmed in type 2 diabetes (OR (95\%CI) 2.51 (1.33-4.74), $p=0.005$; I2 97\%), but not in type 1 diabetes (OR (95\%CI) 2.44 (0.85-6.99), $p=0.100 ;$ I2 77\%). Also, body mass index and diabetes duration were higher in NAFLD subjects compared to those without NAFLD $(p<0.001)$, considering both type 2 and type 1 diabetes. Conclusion. Despite a high heterogeneity among studies, a significantly increased DPN prevalence among type 2 diabetes subjects with NAFLD was observed. This result was not found in type 1 diabetes, probably due to the longer duration of disease. Physicians should pay more attention to the early detection of DPN, especially in patients with NAFLD.

Keywords: NAFLD; diabetes mellitus; peripheral polyneuropathy

\section{Introduction}

Peripheral diabetic polyneuropathy (DPN) is a microvascular complication of diabetes mellitus (DM), representing the most clinically relevant manifestation of typical forms of diabetic neuropathy (DN). DPN has been defined by the Toronto Expert Panel on Diabetic Neuropathy as a symmetrical, length-dependent sensorimotor polyneuropathy attributable to metabolic and microvascular alterations, resulting from the chronic hyperglycemia typical of diabetes and cardiovascular risk covariates [1]. DPN occurs in at least $20 \%$ of people with type $1 \mathrm{DM}$ (T1DM) after 20 years of disease duration, as suggested by large observational cohorts [2,3] and the Diabetes Control and Complications Trial (DCCT)/Epidemiology of Diabetes Interventions and Complications (EDIC) Study [4,5]. Considering type 2 DM (T2DM), DPN has been detected in at least 10-15\% of newly diagnosed patients with T2DM [6,7], and up to 50\% after 10 years of disease duration $[8,9]$. Moreover, DPN has been identified in $11 \%$ to $23 \%$ of people with prediabetes [10]. From a 
clinical point of view, the DPN diagnosis is extremely relevant in DM management, since it confers a predisposition to pain, numbness, ulceration, and amputation of the distal extremities, increasing the risk of all-cause and cardiovascular disease mortality [11-13].

Starting from the clinical relevance of DPN, many authors tried to identify factors able to predict DPN in DM. Till now, diabetes duration and glycemic control, expressed by glycated hemoglobin $(\mathrm{HbA} 1 \mathrm{c})$, represent the main predictive factors [14]. Moreover, metabolic syndrome components, such as hypertriglyceridemia, hypertension, abdominal obesity, and low high-density lipoprotein (HDL) serum levels, are consistently associated with DPN in both T2DM and T1DM $[15,16]$. Alongside metabolic variables, several lifestyle habits have been detected as further correlates, such as smoking, alcohol abuse, height, and older age [15]. In general, many studies suggested that DPN prevalence was higher in cases of concomitant comorbid conditions, such as micro- (nephropathy or retinopathy), macrovascular disease (peripheral arterial disease or cardiovascular disease) and depression [17]. Finally, new biochemical markers have been investigated as potential predictive markers of DPN. In particular, novel systemic biomarkers of oxidative stress (i.e., reactive oxygen species), inflammation (interleukin (IL)-6, and tumor necrosis factor (TNF)-a), and vascular activation, have been linked to distal DPN development [16].

Recently, DPN has been associated with another pathological condition linked to DM and obesity, the nonalcoholic fatty liver disease (NAFLD). NAFLD is a metabolically derangement-based liver disease, defined by the presence of steatosis in more than $5 \%$ of hepatocytes, in association with metabolic risk factors (such as obesity, diabetes, and dyslipidemia) and in the absence of excessive alcohol consumption or other chronic liver diseases [18,19]. NAFLD affects more than $25 \%$ of the global population [20] and is largely demonstrated as highly prevalent in patients with T2DM (60-75\%) [21]. Many studies proved that NAFLD is associated with an increased risk of macro- and microvascular complications in diabetic patients [22-24], notably including albuminuria [25] and retinopathy [26]. Currently, there is little information about the association between NAFLD and DPN, and the available data are scarce and conflicting.

With this in mind, this meta-analysis was conducted to summarize available data estimating the DPN prevalence among diabetic patients with NAFLD. In particular, the study was designed to highlight potential links between NAFLD and DPN in diabetic patients.

\section{Materials and Methods}

This meta-analysis was performed according to the Cochrane Collaboration and PRISMA statement. To ensure originality and transparency of the review process, the metaanalysis was registered in the International Prospective Register of Systematic Reviews (PROSPERO; registration ID 251792).

The literature search was performed until 4 June 2021 considering the following string: $(((((()($ diabetes) OR (type 2 diabetes mellitus)) OR (type 1 diabetes mellitus)) OR (diabetes mellitus)) OR (T2DM)) OR (T1DM)) AND (neuropathy)) OR (peripheral neuropathy)) AND (NAFLD)) OR (non-alcoholic fatty liver disease)) OR (hepatic steatosis). Medline, Embase, and Cochrane databases were considered.

Since the term NAFLD was coined in 1980 to describe fatty liver disease arising in the absence of significant alcohol intake [27], studies published before 1980 were excluded from the analysis. Moreover, since the NAFLD diagnosis could be achieved by different methodologies, we considered studies in which the presence of NAFLD was evaluated either by liver ultrasound, composite non-invasive biomarkers, or ultrasound elastography.

\subsection{Endpoints}

Primary endpoint was the prevalence of peripheral DPN evaluated by either, signs, symptoms, or nerve conduction study (NCS). All variables known to predict DPN were considered as secondary endpoints. In particular, risk factors and clinical correlates of DPN are age, diabetes duration, glycaemic control, arterial hypertension, and smoking [14,28,29]. Thus, the following variables were extracted from the included studies as secondary 
endpoints: patient's age, height, body mass index (BMI), HbA1c, HDL, triglycerides and total cholesterol, C-peptide serum levels, and diabetes duration. Lipid profile-related variables were transformed in $\mathrm{mmol} / \mathrm{L}$ when reported differently in the original works. Moreover, smoking and alcohol habits were extracted when available.

\subsection{Study Selection and Inclusion Criteria}

The literature search evaluated all clinical trials with the following inclusion criteria: (i) either interventional or observational study designs, (ii) in which the DPN prevalence was reported, (iii) in people with DM, and (iv) in which baseline presence or absence of NAFLD was assessed. Both T1DM and T2DM were considered eligible. No specific exclusion criteria have been considered for the studies extracted. Moreover, both longitudinal and cross-sectional studies were included in the analysis. Since the analysis was not focused on a specific pharmacological or not-pharmacological intervention, the randomization was not considered as inclusion criterion.

\subsection{Data Collection Process and Quality}

Two authors (C.G. and D.S.) separately performed the literature search, collecting abstracts of each study. Each abstract was evaluated for inclusion criteria and data were extracted from each study considered eligible. C.G. and D.S. performed quality control checks on extracted data. For the literature search, the primary endpoint was the prevalence of DPN, thus, patients were divided in study and control groups considering the presence or absence of NAFLD, respectively.

The two investigators extracted the following information from the included studies: (i) general characteristics including study design, sample size, and year of publication, (ii) diagnostic methods of NAFLD and of DPN, (iii) the proportion of NAFLD patients and diabetic neuropathy patients, and (iv) adjusted confounders.

All variables were extracted as mean \pm standard difference. When variables were reported as median (interquartile or minimum and maximum) in the original work, they were transformed accordingly.

\subsection{Data Synthesis and Analysis}

The analyses were performed using the Review Manager (RevMan) 5.4 Software (Version 5.4.1, The Nordic Cochrane Centre, The Cochrane Collaboration; Copenhagen, Denmark, 2014). Values of $p<0.05$ were considered statistically significant.

The DPN prevalence was compared between diabetic patients with and without NAFLD, considering the odds ratio obtained applying the Mantel-Haenszel method. The fixed model was initially used, whereas the random effect model was applied in case of $\mathrm{I}^{2}$ higher than $60 \%$. The heterogeneity degree among different studies was examined by inspecting both the scatter in the data points and the overlap in their confidence intervals (CIs), and by performing I $\mathrm{I}^{2}$ statistics. Weighted mean differences and $95 \%$ CIs were estimated for the literature search. Continuous data were expressed as mean differences when reliable methods have been used for detection (i.e., BMI, $\mathrm{HbA1c}$, etc.), whereas standard mean differences were used for other variables (i.e., lipid asset).

Sensitivity analyses were performed in order to reduce the studies' heterogeneity. In particular, patients' inclusion criteria were evaluated and used to divide the included studies. Moreover, sensitivity analyses were performed considering study design, dividing longitudinal from cross-sectional studies. Finally, publication biases were explored through funnel plots [30] and corrected by Duval and Tweedie's 'trim-and-fill' analysis [31]. In the presence of asymmetric funnel shapes, this test detects putative missing studies to rebalance the distribution and provides an adjusted pooled estimate taking the additional studies into account, thus correcting the analysis for publication bias. 


\section{Results}

The literature search identified 2613 papers, after duplication removal. After abstract evaluations, 16 studies were considered for the full text analysis [32-47] (Figure 1). Three studies have been excluded, since one is a duplication of previously published results [45], and two works did not report the prevalence of neuropathy in NAFLD positive and negative patients [43,44] (Figure 1). Finally, 13 cross-sectional studies were included. No longitudinal trials were available on the topic. Table 1 summarizes the characteristics of 13 studies, finally included in the meta-analysis.
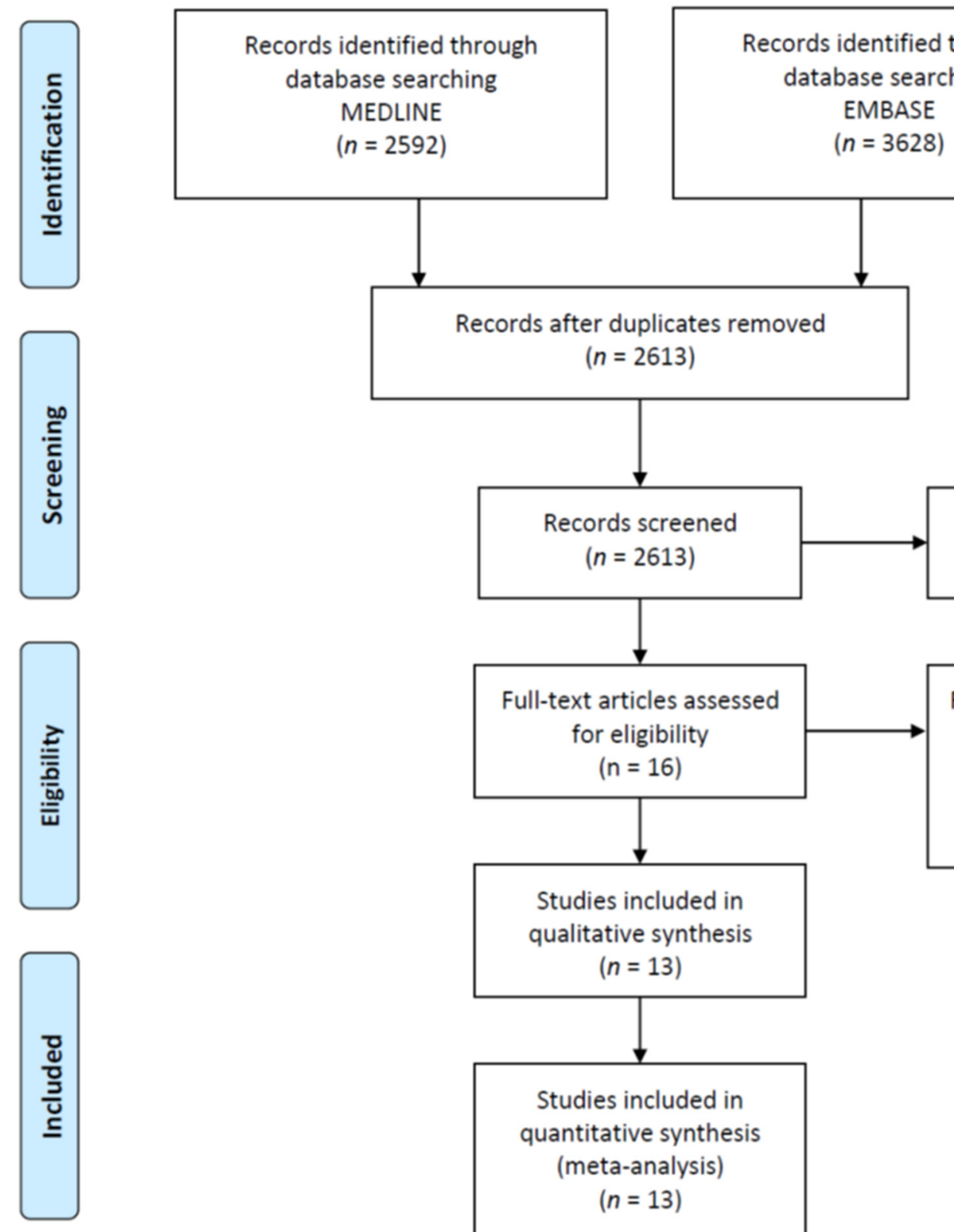

Records excluded ( $n=2595$ )

Studies included in qualitative synthesis $(n=13)$

Full-text articles excluded, with reasons $(n=3)$

$n=1$ : duplicated $n=2$ : data not available

Studies included in quantitative synthesis (meta-analysis) ( $n=13)$

Figure 1. Study flow-chart. 
Table 1. Included studies' characteristics.

\begin{tabular}{|c|c|c|c|c|c|c|c|}
\hline $\begin{array}{l}\text { Author, } \\
\text { Year }\end{array}$ & Country & Study Design & Aim of the Study & $\begin{array}{l}\text { Enrolled Patients } \\
\text { (Number) } \\
\text { and Type of DM }\end{array}$ & Sex & NAFLD Diagnosis & $\begin{array}{c}\text { DPN } \\
\text { Diagnosis }\end{array}$ \\
\hline $\begin{array}{l}\text { Afarideh, } \\
2019\end{array}$ & Iran & Cross-sectional & $\begin{array}{l}\text { To evaluate associations of serum } \\
\text { liver enzymes and NAFLD with } \\
\text { chronic microvascular } \\
\text { complications in patients with T2D }\end{array}$ & $\begin{array}{c}935 \\
\text { New-onset T2DM }\end{array}$ & $\begin{array}{c}\text { Males } 450(48.1 \%) \\
\text { Females } 485(51.9 \%)\end{array}$ & US & DNS score \\
\hline $\begin{array}{l}\mathrm{Hu}, \\
2021\end{array}$ & China & Cross-sectional & $\begin{array}{l}\text { To examine whether serum uric } \\
\text { acid in T2DM is influenced by age, } \\
\text { gender, BMI, lipid, renal function } \\
\text { and other characteristics }\end{array}$ & $\begin{array}{c}2809 \\
\mathrm{~T} 2 \mathrm{DM}\end{array}$ & $\begin{array}{c}\text { Males } 1784(63.5 \%) \\
\text { Females } 1025(36.5 \%)\end{array}$ & $\begin{array}{c}\text { US } \\
(+ \text { reduced alcohol } \\
\text { intake })\end{array}$ & $\begin{array}{c}\text { Physical examination } \\
\text { and NCS }\end{array}$ \\
\hline $\begin{array}{l}\text { Kim, } \\
2014\end{array}$ & Korea & Cross-sectional & $\begin{array}{l}\text { To assess association between } \\
\text { NAFLD and macro- and } \\
\text { micro-vascular complications }\end{array}$ & $\begin{array}{c}929 \\
\mathrm{~T} 2 \mathrm{DM}\end{array}$ & $\begin{array}{c}\text { Males } 489(52.6 \%) \\
\text { Females } 440(47.4 \%)\end{array}$ & US & $\begin{array}{l}\text { Physical examination } \\
\text { and NCS }\end{array}$ \\
\hline $\begin{array}{l}\text { Leite, } \\
2021\end{array}$ & Brazil & Cross-sectional & $\begin{array}{l}\text { To evaluate the NAFLD fibrosis } \\
\text { score as predictors of complications } \\
\text { development and mortality }\end{array}$ & $\begin{array}{c}554 \\
\mathrm{~T} 2 \mathrm{DM}\end{array}$ & $\begin{array}{c}\text { Males } 218(39.4 \%) \\
\text { Females } 336(60.6 \%)\end{array}$ & US + NFS & Physical examination \\
\hline $\begin{array}{l}\text { Lv, } \\
2013\end{array}$ & Cina & Cross-sectional & $\begin{array}{l}\text { To determine the prevalence and } \\
\text { risk factors for NAFLD and } \\
\text { evaluated its correlations with } \\
\text { microvascular complications }\end{array}$ & $\begin{array}{l}1217 \\
\mathrm{~T} 2 \mathrm{DM}\end{array}$ & $\begin{array}{c}\text { Males } 460(37.8 \%) \\
\text { Females } 757(62.2 \%)\end{array}$ & $\begin{array}{c}\text { US } \\
\text { (+absence of a } \\
\text { secondary cause of } \\
\text { steatosis) }\end{array}$ & Physical examination \\
\hline $\begin{array}{l}\text { Mantovani, } \\
2017\end{array}$ & Italy & Cross-sectional & $\begin{array}{l}\text { To assess association between } \\
\text { NAFLD and DPN }\end{array}$ & $\begin{array}{c}286 \\
\text { T1DM }\end{array}$ & $\begin{array}{c}\text { Males } 121(42.3 \%) \\
\text { Females } 165(57.7 \%)\end{array}$ & US & $\begin{array}{l}\text { MNSI score } \\
\text { and VPT }\end{array}$ \\
\hline $\begin{array}{l}\text { Mikolasevic } \\
2021\end{array}$ & Croatia & Cross-sectional & $\begin{array}{l}\text { To examine whether NAFLD is } \\
\text { associated with } \\
\text { chronic vascular complications } \\
\text { of T2DM }\end{array}$ & $\begin{array}{c}442 \\
\mathrm{~T} 2 \mathrm{DM}\end{array}$ & $\begin{array}{c}\text { Males } 209(47.3 \%) \\
\text { Females } 233(52.7 \%)\end{array}$ & FibroScan & $\begin{array}{c}\text { Physical examination } \\
\text { and NCS }\end{array}$ \\
\hline
\end{tabular}


Table 1. Cont.

\begin{tabular}{|c|c|c|c|c|c|c|c|}
\hline $\begin{array}{l}\text { Author, } \\
\text { Year }\end{array}$ & Country & Study Design & Aim of the Study & $\begin{array}{l}\text { Enrolled Patients } \\
\text { (Number) } \\
\text { and Type of DM }\end{array}$ & Sex & NAFLD Diagnosis & $\begin{array}{c}\text { DPN } \\
\text { Diagnosis }\end{array}$ \\
\hline $\begin{array}{l}\text { Tripolino, } \\
2019\end{array}$ & Italy & Cross-sectional & $\begin{array}{l}\text { To evaluate association between } \\
\text { NAFLD and complications }\end{array}$ & $\begin{array}{c}124 \\
\text { T1DM }\end{array}$ & $\begin{array}{c}\text { Males } 68(60.7 \%) \\
\text { Females } 44(39.3 \%)\end{array}$ & HSI & $\begin{array}{l}\text { Physical examination } \\
\text { and NCS }\end{array}$ \\
\hline $\begin{array}{l}\text { Vendhan, } \\
2014\end{array}$ & India & Cross-sectional & $\begin{array}{l}\text { To estimate the prevalence and } \\
\text { clinical profile of NAFLD }\end{array}$ & $\begin{array}{c}736 \\
\text { T1DM }\end{array}$ & $\begin{array}{c}\text { Males } 384(52 \%) \\
\text { Females } 354(48 \%)\end{array}$ & US & VPT \\
\hline $\begin{array}{l}\text { Williams, } \\
2015\end{array}$ & Australia & Cross-sectional & $\begin{array}{c}\text { To examine the association } \\
\text { between distal VPT and NAFLD }\end{array}$ & $\begin{array}{c}456 \\
\text { T2DM }\end{array}$ & $\begin{array}{c}\text { Males } 270(59.2 \%) \\
\text { Females } 186(40.8 \%)\end{array}$ & US & VPT \\
\hline $\begin{array}{l}\text { Yan, } \\
2016\end{array}$ & China & Cross-sectional & $\begin{array}{c}\text { To explore differences in } \\
\text { complications when NAFLD } \\
\text { developed with pre-existing T2DM }\end{array}$ & $\begin{array}{c}212 \\
\mathrm{~T} 2 \mathrm{DM}\end{array}$ & $\begin{array}{l}\text { Males } 120(56.6 \%) \\
\text { Females } 92(43.4 \%)\end{array}$ & US & Physical examination \\
\hline $\begin{array}{l}\text { Huang, } \\
2021\end{array}$ & China & Cross-sectional & $\begin{array}{l}\text { To evaluate the relationship } \\
\text { between NAFLD and DPN }\end{array}$ & $\begin{array}{c}520 \\
\text { T2DM }\end{array}$ & $\begin{array}{c}\text { Males } 227(43.7 \%) \\
\text { Females } 293(56.3 \%)\end{array}$ & FibroScan & $\begin{array}{l}\text { Physical examination } \\
\text { and NCS }\end{array}$ \\
\hline
\end{tabular}

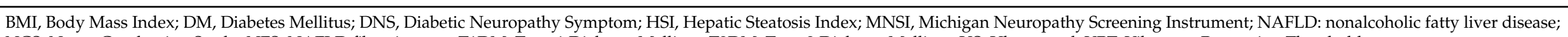
NCS, Nerve Conduction Study; NFS, NAFLD fibrosis score; T1DM, Type 1 Diabetes Mellitus; T2DM, Type 2 Diabetes Mellitus; US, Ultrasound; VPT, Vibratory Perception Threshold. 
A total of 9614 diabetic patients were included in the analysis. The majority of studies (77\%) evaluated T2DM patients and only three studies (23\%) enrolled subjects with T1DM. All included studies enrolled both males and females, thus the role of gender could be not ruled out.

DPN prevalence was significantly higher in diabetic patients with NALFD, compared to patients without NAFLD ( $p=0.001)$ (Figure 2). In particular, the prevalence of DPN was significantly higher in patients with NAFLD compared to patients without it, considering T2DM $(p=0.005)$, but not T1DM $(p=0.100)$ (Figure 2$)$.

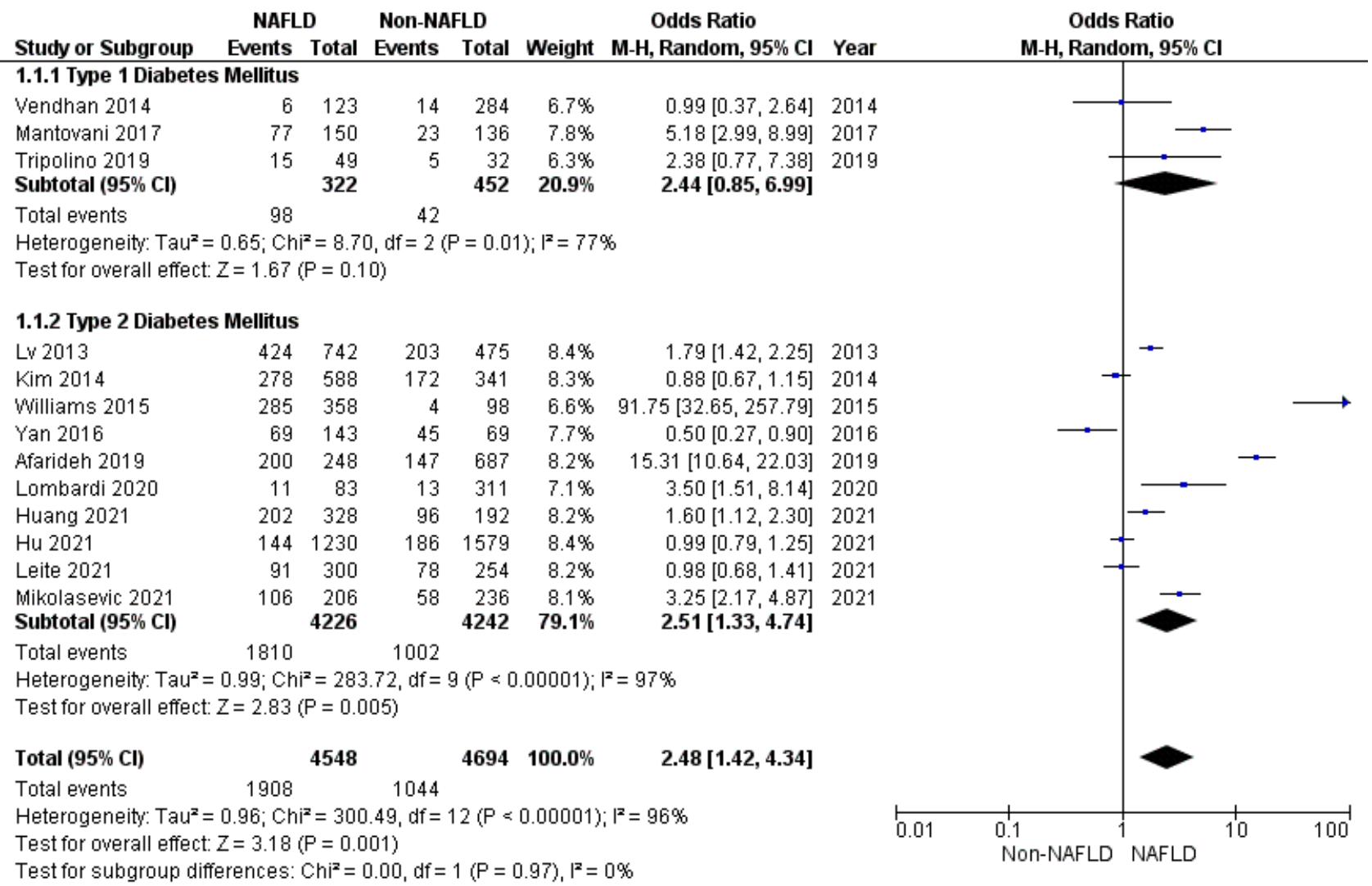

Figure 2. Forrest plot displaying the prevalence of peripheral neuropathy expressed as odds ratio, comparing diabetic patients with and without NAFLD.

\subsection{Secondary Endpoints}

Secondary endpoints were considered in patients with (study group) and without (control group) NAFLD in order to evaluate which variables could affect the association with DPN. However, despite the large literature supporting the predictive role of several parameters on NAFLD, not all studies included in our meta-analysis reported these endpoints. Indeed, C-peptide, for example, was reported only in two included studies [34,40] and it could not be meta-analyzed. Similarly, smoking and alcohol habits were reported in a limited number of studies, not allowing a meta-analytic comprehensive evaluation.

In this setting, no differences in the age of patients in the study compared to control groups were observed (mean difference -0.3 : $95 \% \mathrm{CI}-1.9,1.4$ years, $p=0.720$ ). The comparison between study and control groups in males and females separately was not performed, since the DPN percentage was not reported in each gender separately.

On the contrary, anthropometric variables demonstrated a potential predictive role. Indeed, BMI, reported in 11 included studies, was higher in the studies compared to control groups $(p<0.001)$, considering both T2DM $(p<0.001)$ and T1DM $(p=0.030)$ (Figure 3$)$. 


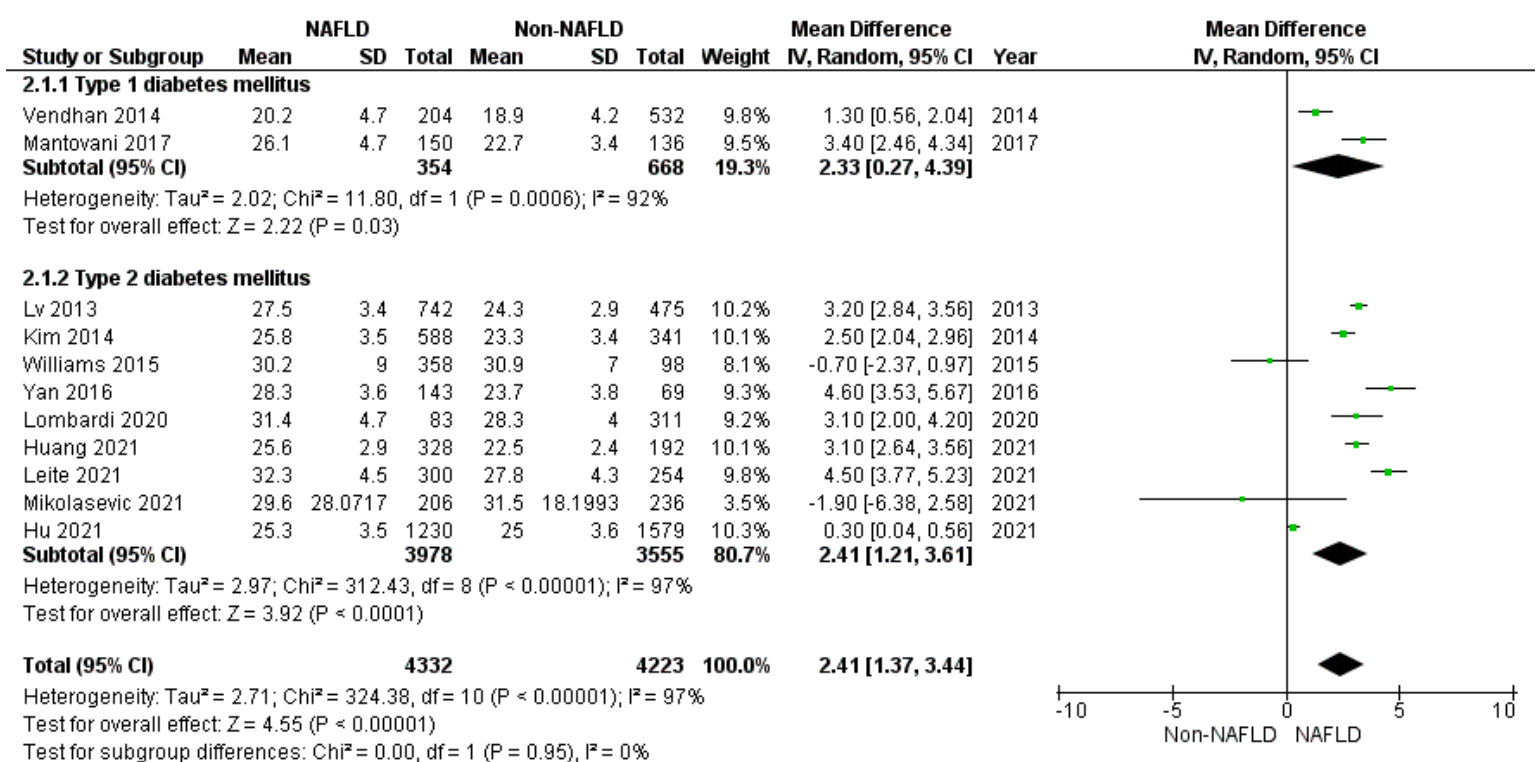

Figure 3. Forrest plot demonstrating the body mass index (BMI) comparing diabetic patients with and without NAFLD. Data are expressed as the mean difference and evaluated by applying the random effect model.

Considering diabetes duration and control, patients with NAFLD demonstrated no different HbA1c serum levels $(p=0.060)$ compared to controls (mean difference: 1.25 , 95\%CI: $-0.07,2.57$ ), neither in T2DM (mean difference: $0.29,95 \%$ CI: $-0.58,1.16, p=0.510$ ) nor in T1DM (mean difference: 6.49, 95\%CI: -14.09, 27.07, $p=0.540$ ); HbA1c serum levels were different between study and control groups. On the contrary, diabetes duration was significantly higher in the study than in control groups $(p<0.001)$, also considering T2DM $(p=0.006)$ and T1DM $(p=0.030)$ alone (Figure 4$)$.

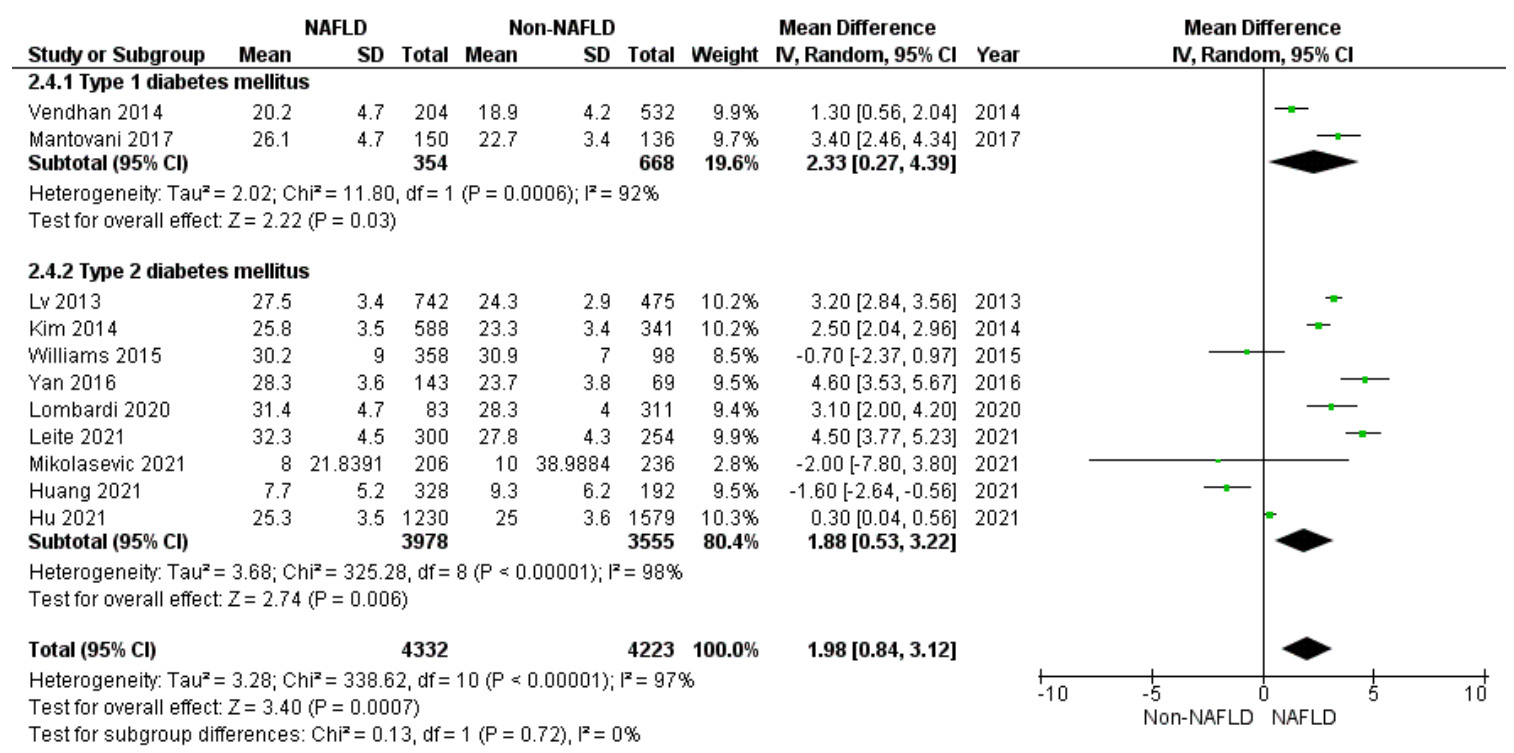

Figure 4. Forrest plot displaying diabetes duration in years, comparing diabetic patients with and without NAFLD. Data are expressed as a mean difference, evaluated by applying the random effect model.

Considering the lipid profile, total $(p=0.250)$ (Figure 5), HDL (standard mean difference -0.13 : $95 \% \mathrm{CI}:-0.26,0.01 \mathrm{mmol} / \mathrm{L}, p=0.060$ ), and cholesterol and triglycerides $(p=0.050)$ (Figure 6$)$ did not differ between study and control groups. However, sensitivity analyses demonstrated higher total $(p=0.010)$ cholesterol levels in patients with NAFLD 
and T2DM, but not in T1DM (Figure 5). On the contrary, HDL cholesterol did not differ between the study and control groups in T2DM (standard mean difference $-0.11: 95 \% \mathrm{CI}$ : $-0.25,0.03 \mathrm{mmol} / \mathrm{L}, p=0.130)$ and T1DM $(-0.24: 95 \% \mathrm{CI}:-0.73,0.25 \mathrm{mmol} / \mathrm{L}, p=0.330)$, separately. Finally, triglycerides were significantly higher in the study groups compared to the controls in T2DM $(p<0.001)$ and lower in T1DM $(p=0.009)$ (Figure 6).

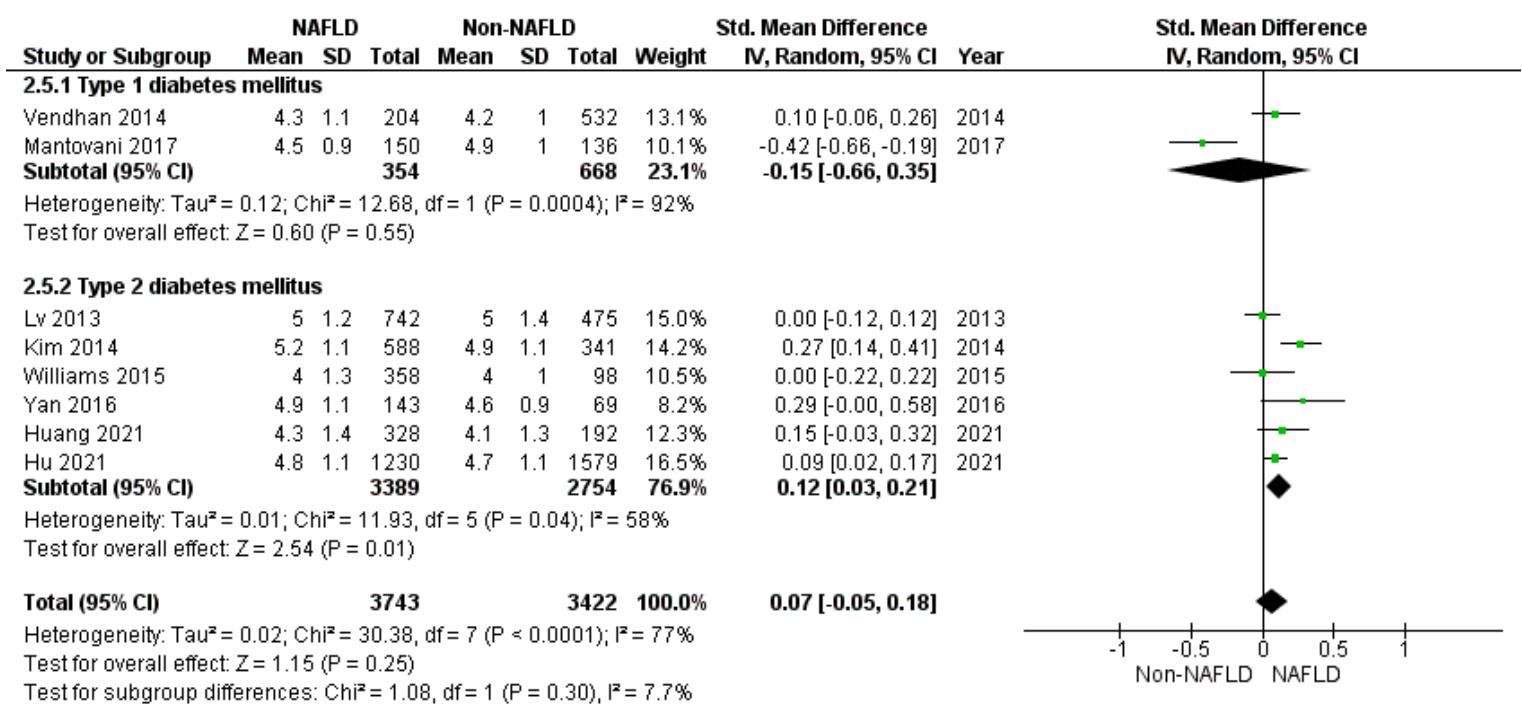

Figure 5. Forrest plot displaying total cholesterol serum levels expressed in mmol/L, comparing diabetic patients with and without NAFLD. Data are expressed as a standard mean difference, evaluated by applying a random effect model.

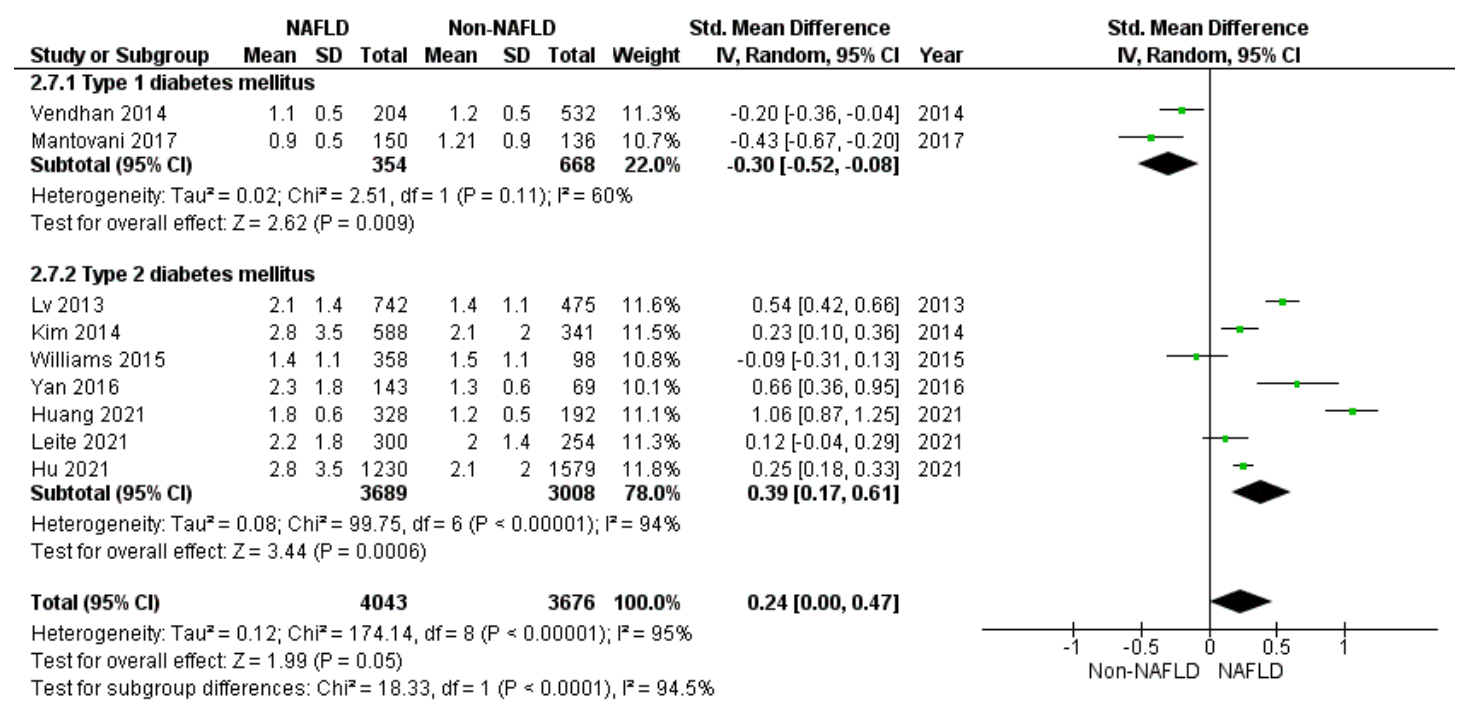

Figure 6. Forrest plot displaying triglycerides serum levels expressed in mmol/L, comparing diabetic patients with and without NAFLD. Data are expressed as a standard mean difference, evaluated by applying the random effect model.

\subsection{Sensitivity Analyses}

In order to reduce the high heterogeneity among studies $\left(\mathrm{I}^{2}=97 \%\right.$, Figure 2$)$, sensitivity analyses were conducted selecting those patients' criteria that were significantly different between the study and control groups. Thus, sensitivity analyses were performed considering the patients' BMI and diabetes duration. Moreover, since the diagnostic methods used to define DPN and NAFLD were variable between studies, further sensitivity analyses were performed considering these factors.

First, studies were divided in three groups according to patients' BMI: normal weight (mean BMI $<25 \mathrm{~kg} / \mathrm{m}^{2}$; number of studies: 4), overweight (BMI between 25 and $30 \mathrm{~kg} / \mathrm{m}^{2}$; 
number of studies: 2), and obesity (BMI $>30 \mathrm{~kg} / \mathrm{m}^{2}$; number of studies: 3 ). The studies' heterogeneity remained high in three groups $(92,94$, and $97 \%$, respectively). Moreover, the limited number of studies in each subgroup reduced the statistical significance of the association between DPN and NAFLD (BMI $<25 \mathrm{~kg} / \mathrm{m}^{2}$ OR (95\% CI) $1.36(0.69-2.69), p=0.380$; BMI between 25 and $30 \mathrm{~kg} / \mathrm{m}^{2}$ OR (95\% CI) $0.97(0.28-3.40), p=0.960 ; \mathrm{BMI}>30 \mathrm{~kg} / \mathrm{m}^{2}$ OR (95\% CI) $4.58(0.24-5.91), p=0.310)$. Second, studies were divided according to diabetes duration in "recent diagnosis", when DM lasted less than 5 years (number of studies: 7) and "long-term diagnosis", when the diagnosis dated more than 5 years before (number of studies: 6). DPN prevalence remained significantly higher in diabetic patients with NAFLD and longer DM diagnosis (OR $\left.(95 \% \mathrm{CI}) 3.13(1.32-8.70), p=0.009 ; \mathrm{I}^{2} 95 \%\right)$, but not in those with shorter diagnosis (OR (95\% CI) $\left.0.99(0.18-3.67), p=0.980 ; \mathrm{I}^{2} 97 \%\right)$. Third, studies were divided in two groups, according to the diagnostic criteria of DPN. In particular, probable neuropathy was defined when only signs and symptoms have been considered (number of studies: 7), whereas confirmed neuropathy was defined by NCS (number of studies: 4). However, also this subdivision did not reduce the heterogeneity among studies (probable DPN: OR (95\% CI) 3.41 (1.28-9.05), $p=0.010 ; I^{2}$ 97\%; confirmed DPN OR (95\% CI) 2.44 (1.19-3.12), $p=0.020 ; I^{2} 91 \%$ ). Finally, studies were divided according to the method applied for NAFLD diagnosis in ultrasound-based diagnosis (number of studies: 10) and Fibroscan-based diagnosis (number of studies: 3 ). DPN prevalence remained significantly higher in diabetic patients with NALFD detected using ultrasound methods (OR (95\% CI) 2.43 (1.21-4.89), $p=0.002 ; \mathrm{I}^{2}$ 97\%), but not using Fibroscan (OR (95\% CI) 0.98 (0.30-3.23), $\left.p=0.970 ; \mathrm{I}^{2} 97 \%\right)$. This latter finding, however, seems to be due to the low number of studies using this methodology.

\subsection{Publication Bias}

Although the asymmetric shape of the funnel plot suggested a possible publication bias (Figure 7), in particular regarding studies enrolling T2DM, the trim-and-fill analysis did not identify putative missing studies.

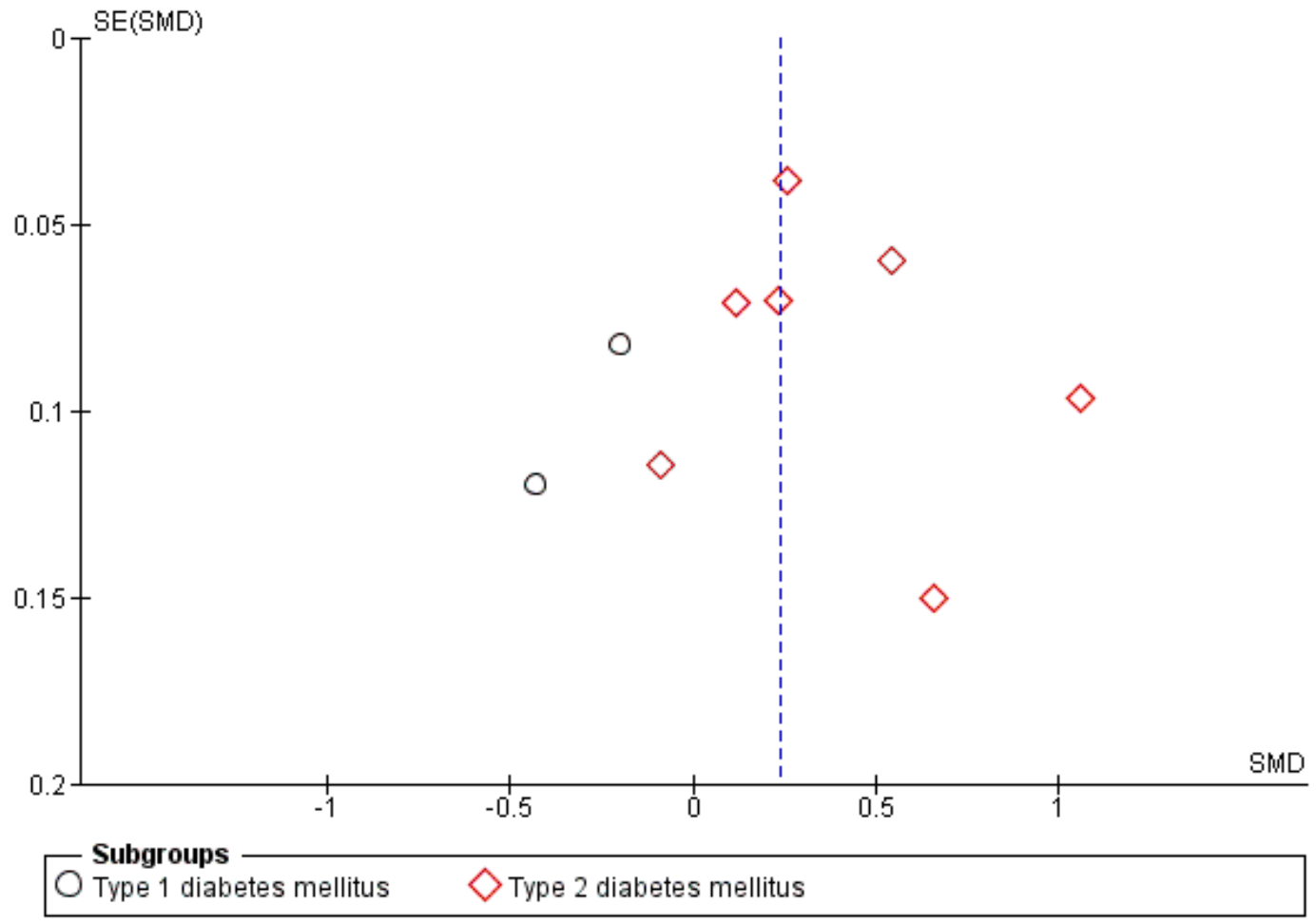

Figure 7. Funnel plot of the results from studies assessing the neuropathy prevalence in diabetic patients with NAFLD. SE: standard error, SMD: standardized mean difference. 


\section{Discussion}

Several studies have been designed to explore the impact of NAFLD on DPN prevalence in both T1DM and T2DM patients so far, but this is the first attempt to systematically combine these results together in a meta-analysis. We demonstrate that DPN is more frequent when NAFLD is associated to DM, evaluating more than 9000 diabetic subjects. This result has an immediate clinical translation. Indeed, we clearly demonstrate that a diabetic patient must be carefully evaluated for the onset of peripheral neurological complications, especially when NAFLD is associated with diabetes. This is particularly true in T2DM or in T1DM and advancing age. Indeed, we demonstrate that DPN risk in T1DM is higher when the diabetes duration is longer, confirming that the long disease duration could be a confounding factor for DPN development. Moreover, here we highlight how NAFLD in $\mathrm{DM}$ is strictly related to high $\mathrm{BMI}$ and diabetes duration, confirming how the prevention of the DM complications must necessarily involve attention to weight gain. In details, NAFLD determines a complex array of metabolic and extra-hepatic consequences, which result from the intra-hepatic deposition of ectopic fat. This condition strongly correlates with abdominal obesity, insulin resistance, and all components of metabolic syndrome. Notably, obesity is one of the clinical correlates of PND in DM2 people. Therefore, obesity itself could represent a confounding factor of the association between NAFLD and PND, at least in DM2.

The link between NAFLD and microvascular complications in diabetic patients is based so far only on association studies, but the cause-effect relationship is far from being completely elucidated. In particular, NAFLD has been suggested as an independent predictor for diabetic kidney disease and proliferative diabetic retinopathy in patients with T2DM $[48,49]$, while the association with DPN is more debated. Thus, NAFLD has been considered as a risk factor for organ-specific complications of DM. What is largely supposed is that NAFLD could exacerbate insulin resistance, impairs dyslipidemia, and predisposes vessels to atherogenic damages, throughout the release of pro-inflammatory, pro-coagulant, and pro-atherogenic factors [50-52]. Moreover, NAFLD induces those damages leading to endothelial dysfunction, predisposing to vascular diseases [53].

In particular, considering DPN, the pathogenetic relationship with NAFLD is still under debate. From one side, the metabolic asset leading to NAFLD is largely considered among the risk factors for DPN development. Moreover, in addition to the known metabolic correlates, the possible molecular mediators linking NAFLD with DPN could include the increased release of some pathogenic mediators from the liver, such as advanced glycation end-products, reactive oxygen species, C reactive protein, IL- 6 , and TNF- $\alpha$, as also suggested for retinopathy and chronic kidney disease [49].

NAFLD natural history describes early stages, typically asymptomatic, with only incidental finding of abnormal liver enzymes, such as raised plasma alanine aminotransferase (ALT), aspartate transaminase (AST), and / or gamma-glutamyltransferase ( $\gamma \mathrm{GT})$ [54]. However, since liver enzymes largely fluctuate in NAFLD patients, they are not routinely considered as clinical markers of NAFLD diagnosis or severity $[18,55,56]$. Thus, the use of imaging techniques, such as ultrasound, is generally applied as a first line diagnostic step in evaluating hepatic steatosis, also considering its safety and availability, and low cost [57]. With this in mind and considering the main result of our meta-analysis, it is clear that diabetic patients must undergo hepatic ultrasound evaluation in order to precociously detect the presence of NAFLD. However, NAFLD severity could also have a role in comorbidities development. The gold standard to detect NAFLD severity, in terms of steatosis amount, necro-inflammation, and fibrosis is represented by liver biopsy [18] that is not suitable for large-scale screening purposes, due to invasiveness and costs. Several emerging non-invasive techniques, notably including composite biomarkers, ultrasound elastography, or magnetic resonance, display good performance in evaluating NAFLD severity and have been proposed for widespread use in clinical practice. Unfortunately, only a minority of studies enrolled in our meta-analysis evaluated NAFLD severity, pre- 
venting us from a reliable analysis of such data. Future studies should be designed to identify whether NAFLD severity could predict the DPN development.

The result of this meta-analysis provides a clear snapshot on what we know about the association among DM, NAFLD, and peripheral DPN. This setting, however, is very heterogeneous. Indeed, all studies enrolled are population-based matched case-control studies, with a clear difference among inclusion and exclusion criteria. Moreover, only in 7 out of 13 studies the aim of the study was the evaluation of the prevalence of microvascular complications in diabetic patients. In the remaining part, the peripheral DPN has been assessed in relation to specific clinic or biochemical characteristics of enrolled patients, such as uric acid or liver fibrosis. Thus, the approach to our study question (i.e., whether NAFLD predisposes to peripheral DPN in patients with DM) is widely different, limiting the robustness of a comprehensive evaluation. Moreover, the peripheral DPN can be probable and confirmed, according to the diagnostic path followed. In particular, only when NCS is performed, a confirmed diagnosis should be reached. Our meta-analysis collected only six studies in which a confirmed DPN could be verified, increasing the heterogeneity among studies. Furthermore, the clinical management of patients enrolled in each study is extremely variable. In particular, diabetic comorbidities and complications management could have a significant role in DPN development. Here, however, we could not adjust the meta-analytic approach with the therapies applied to enrolled patients. This could lead to confounding results considering secondary endpoints. As a confirmation, we highlight that lipid profile does not change between the study and control group, although several studies suggested a worse lipid profile in patients with NAFLD [58-60]. Thus, we could not speculate in favour or in contrast to dyslipidaemia as a factor linking NAFLD and peripheral neuropathy in diabetic patients.

Our study presents several limitations. First, this is a meta- analysis and could not determine causal relations. Second, we found considerable heterogeneity among studies, which limits the exportability of our results. Third, the diagnostic criteria for DPN displays some methodological heterogeneity, resulting in a probable diagnosis in some studies and a confirmed diagnosis of DPN in others. Furthermore, in enrolled trials, the diagnostic method used to evaluate NAFLD was quite heterogeneous, and liver biopsies, which are the gold standard to evaluate NAFLD severity and may play a probable role in DPN onset and progression, were not performed in any study. Finally, differences in country and geographic origin among studies may be one of the sources of heterogeneity, which should be treated with caution and confirmed in further research. Despite these limitations, these results suggest, in a very large sample, that DM combined with NAFLD is positively associated with peripheral DPN.

\section{Conclusions}

The present meta-analysis suggests a significantly increased DPN prevalence among diabetic patients with NAFLD, in particular in the case of T2DM. Indeed, T2DM combined with NAFLD demonstrated a higher prevalence of peripheral DPN than the T2DM-alone group. This result has not been confirmed in T1DM, likely due to the longer duration of disease as a confounding factor. Moreover, our findings confirm that NAFLD in DM is strictly related to high BMI and also to diabetes duration. In conclusion, these results suggest that physicians should pay more attention to the early detection of DPN, especially in patients with NAFLD. Lastly, large-scale prospective studies are required to elucidate causal associations between NAFLD and the microvascular complications, including DPN, in diabetic people.

Author Contributions: Conceptualization, C.G., D.S. and F.N.; methodology, C.G. and D.S.; formal analysis, D.S.; data curation, D.S.; writing—original draft preparation, C.G. and D.S.; writing-review and editing, C.G., D.S., F.N., M.S., F.C. and P.A. All authors have read and agreed to the published version of the manuscript.

Funding: This research received no external funding. 
Institutional Review Board Statement: Not requested for this type of study.

Informed Consent Statement: Not requested for this type of study.

Data Availability Statement: Derived data supporting the findings of this study are available from the corresponding author on request.

Conflicts of Interest: The authors declare no conflict of interest.

\section{References}

1. Tesfaye, S.; Boulton, A.J.; Dyck, P.J.; Freeman, R.; Horowitz, M.; Kempler, P.; Lauria, G.; Malik, R.A.; Spallone, V.; Vinik, A.; et al. Diabetic neuropathies: Update on definitions, diagnostic criteria, estimation of severity, and treatments. Diabetes Care 2010, 33, 2285-2293. [CrossRef]

2. Maser, R.E.; Steenkiste, A.R.; Dorman, J.S.; Nielsen, V.K.; Bass, E.B.; Manjoo, Q.; Drash, A.L.; Becker, D.J.; Kuller, L.H.; Greene, D.A. Epidemiological correlates of diabetic neuropathy. Report from Pittsburgh Epidemiology of Diabetes Complications Study. Diabetes 1989, 38, 1456-1461. [CrossRef]

3. Tesfaye, S.; Stevens, L.K.; Stephenson, J.M.; Fuller, J.H.; Plater, M.; Ionescu-Tirgoviste, C.; Nuber, A.; Pozza, G.; Ward, J.D. Prevalence of diabetic peripheral neuropathy and its relation to glycaemic control and potential risk factors: The EURODIAB IDDM Complications Study. Diabetologia 1996, 39, 1377-1384. [CrossRef]

4. Martin, C.L.; Albers, J.W.; Pop-Busui, R.; DCCT/EDIC Research Group. Neuropathy and related findings in the diabetes control and complications trial/epidemiology of diabetes interventions and complications study. Diabetes Care 2014, 37, 31-38. [CrossRef]

5. Albers, J.W.; Herman, W.H.; Pop-Busui, R.; Feldman, E.L.; Martin, C.L.; Cleary, P.A.; Waberski, B.H.; Lachin, J.M.; Diabetes Control and Complications Trial/Epidemiology of Diabetes Interventions and Complications Research Group. Effect of prior intensive insulin treatment during the Diabetes Control and Complications Trial (DCCT) on peripheral neuropathy in type 1 diabetes during the Epidemiology of Diabetes Interventions and Complications (EDIC) Study. Diabetes Care 2010, 33, 1090-1096. [CrossRef]

6. Young, M.J.; Boulton, A.J.; MacLeod, A.F.; Williams, D.R.; Sonksen, P.H. A multicentre study of the prevalence of diabetic peripheral neuropathy in the United Kingdom hospital clinic population. Diabetologia 1993, 36, 150-154. [CrossRef]

7. UK Prospective Diabetes Study (UKPDS) Group. Intensive blood-glucose control with sulphonylureas or insulin compared with conventional treatment and risk of complications in patients with type 2 diabetes (UKPDS 33). Lancet 1998, 352, 837-853. [CrossRef]

8. Ang, L.; Jaiswal, M.; Martin, C.; Pop-Busui, R. Glucose control and diabetic neuropathy: Lessons from recent large clinical trials. Curr. Diabetes Rep. 2014, 14, 528. [CrossRef]

9. Pop-Busui, R.; Lu, J.; Brooks, M.M.; Albert, S.; Althouse, A.D.; Escobedo, J.; Green, J.; Palumbo, P.; Perkins, B.A.; Whitehouse, F.; et al. Impact of glycemic control strategies on the progression of diabetic peripheral neuropathy in the Bypass Angioplasty Revascularization Investigation 2 Diabetes (BARI 2D) Cohort. Diabetes Care 2013, 36, 3208-3215. [CrossRef]

10. Papanas, N.; Vinik, A.I.; Ziegler, D. Neuropathy in prediabetes: Does the clock start ticking early? Nat. Rev. Endocrinol. 2011, 7, 682-690. [CrossRef]

11. Forsblom, C.M.; Sane, T.; Groop, P.H.; Tötterman, K.J.; Kallio, M.; Saloranta, C.; Laasonen, L.; Summanen, P.; Lepäntalo, M.; Laatikainen, L.; et al. Risk factors for mortality in Type II (non-insulin-dependent) diabetes: Evidence of a role for neuropathy and a protective effect of HLA-DR4. Diabetologia 1998, 41, 1253-1262. [CrossRef]

12. Soedamah-Muthu, S.S.; Chaturvedi, N.; Witte, D.R.; Stevens, L.K.; Porta, M.; Fuller, J.H.; EURODIAB Prospective Complications Study Group. Relationship between risk factors and mortality in type 1 diabetic patients in Europe: The EURODIAB Prospective Complications Study (PCS). Diabetes Care 2008, 31, 1360-1366. [CrossRef]

13. Coppini, D.V.; Bowtell, P.A.; Weng, C.; Young, P.J.; Sönksen, P.H. Showing neuropathy is related to increased mortality in diabetic patients-A survival analysis using an accelerated failure time model. J. Clin. Epidemiol. 2000, 53, 519-523. [CrossRef]

14. Tesfaye, S.; Chaturvedi, N.; Eaton, S.E.; Ward, J.D.; Manes, C.; Ionescu-Tirgoviste, C.; Witte, D.R.; Fuller, J.H.; EURODIAB Prospective Complications Study Group. Vascular risk factors and diabetic neuropathy. N. Engl. J. Med. 2005, 352, 341-350. [CrossRef]

15. Feldman, E.L.; Callaghan, B.C.; Pop-Busui, R.; Zochodne, D.W.; Wright, D.E.; Bennett, D.L.; Bril, V.; Russell, J.W.; Viswanathan, V. Diabetic neuropathy. Nat. Rev. Dis. Prim. 2019, 5, 41. [CrossRef]

16. Bönhof, G.J.; Herder, C.; Strom, A.; Papanas, N.; Roden, M.; Ziegler, D. Emerging Biomarkers, Tools, and Treatments for Diabetic Polyneuropathy. Endocr. Rev. 2019, 40, 153-192. [CrossRef]

17. Ziegler, D.; Papanas, N.; Vinik, A.I.; Shaw, J.E. Epidemiology of polyneuropathy in diabetes and prediabetes. Handb. Clin. Neurol. 2014, 126, 3-22. [CrossRef]

18. European Association for the Study of the Liver (EASL); European Association for the Study of Diabetes (EASD); European Association for the Study of Obesity (EASO). EASL-EASD-EASO Clinical Practice Guidelines for the management of non-alcoholic fatty liver disease. J. Hepatol. 2016, 64, 1388-1402. [CrossRef]

19. Chalasani, N.; Younossi, Z.; Lavine, J.E.; Charlton, M.; Cusi, K.; Rinella, M.; Harrison, S.A.; Brunt, E.M.; Sanyal, A.J. The diagnosis and management of nonalcoholic fatty liver disease: Practice guidance from the American Association for the Study of Liver Diseases. Hepatology 2018, 67, 328-357. [CrossRef] 
20. Younossi, Z.M.; Corey, K.E.; Lim, J.K. AGA Clinical Practice Update on Lifestyle Modification Using Diet and Exercise to Achieve Weight Loss in the Management of Nonalcoholic Fatty Liver Disease: Expert Review. Gastroenterology 2021, 160, 912-918. [CrossRef]

21. Younossi, Z.M.; Koenig, A.B.; Abdelatif, D.; Fazel, Y.; Henry, L.; Wymer, M. Global epidemiology of nonalcoholic fatty liver disease-Meta-analytic assessment of prevalence, incidence, and outcomes. Hepatology 2016, 64, 73-84. [CrossRef] [PubMed]

22. Alkagiet, S.; Papagiannis, A.; Tziomalos, K. Associations between nonalcoholic fatty liver disease and ischemic stroke. World J. Hepatol. 2018, 10, 474-478. [CrossRef] [PubMed]

23. Targher, G.; Bertolini, L.; Padovani, R.; Poli, F.; Scala, L.; Tessari, R.; Zenari, L.; Falezza, G. Increased prevalence of cardiovascular disease in Type 2 diabetic patients with non-alcoholic fatty liver disease. Diabet. Med. 2006, 23, 403-409. [CrossRef] [PubMed]

24. Targher, G.; Bertolini, L.; Padovani, R.; Rodella, S.; Tessari, R.; Zenari, L.; Day, C.; Arcaro, G. Prevalence of nonalcoholic fatty liver disease and its association with cardiovascular disease among type 2 diabetic patients. Diabetes Care 2007, 30, 1212-1218. [CrossRef] [PubMed]

25. Wijarnpreecha, K.; Thongprayoon, C.; Boonpheng, B.; Panjawatanan, P.; Sharma, K.; Ungprasert, P.; Pungpapong, S.; Cheungpasitporn, W. Nonalcoholic fatty liver disease and albuminuria: A systematic review and meta-analysis. Eur. J. Gastroenterol. Hepatol. 2018, 30, 986-994. [CrossRef] [PubMed]

26. Song, D.; Li, C.; Wang, Z.; Zhao, Y.; Shen, B.; Zhao, W. Association of non-alcoholic fatty liver disease with diabetic retinopathy in type 2 diabetic patients: A meta-analysis of observational studies. J. Diabetes Investig. 2020, 12, 1471-1479. [CrossRef]

27. Ludwig, J.; Viggiano, T.R.; McGill, D.B.; Oh, B.J. Nonalcoholic steatohepatitis: Mayo Clinic experiences with a hitherto unnamed disease. Mayo Clin. Proc. 1980, 55, 434-438.

28. Ziegler, D. Treatment of diabetic neuropathy and neuropathic pain: How far have we come? Diabetes Care 2008, 31 (Suppl. S2), S255-S261. [CrossRef]

29. Panero, F.; Novelli, G.; Zucco, C.; Fornengo, P.; Perotto, M.; Segre, O.; Grassi, G.; Cavallo-Perin, P.; Bruno, G. Fasting plasma C-peptide and micro- and macrovascular complications in a large clinic-based cohort of type 1 diabetic patients. Diabetes Care 2009, 32, 301-305. [CrossRef]

30. Sterne, J.A.; Egger, M. Funnel plots for detecting bias in meta-analysis: Guidelines on choice of axis. J. Clin. Epidemiol. 2001, 54, 1046-1055. [CrossRef]

31. Duval, S.; Tweedie, R. Trim and fill: A simple funnel-plot-based method of testing and adjusting for publication bias in meta-analysis. Biometrics 2000, 56, 455-463. [CrossRef]

32. Afarideh, M.; Aryan, Z.; Ghajar, A.; Ganji, M.; Ghaemi, F.; Saadat, M.; Heidari, B.; Mechanick, J.I.; Esteghamati, A. Association of non-alcoholic fatty liver disease with microvascular complications of type 2 diabetes. Prim. Care Diabetes 2019, 13, 505-514. [CrossRef]

33. Hu, Y.; Li, Q.; Min, R.; Deng, Y.; Xu, Y.; Gao, L. The association between serum uric acid and diabetic complications in patients with type 2 diabetes mellitus by gender: A cross-sectional study. PeerJ 2021, 9, e10691. [CrossRef] [PubMed]

34. Kim, B.Y.; Jung, C.H.; Mok, J.O.; Kang, S.K.; Kim, C.H. Prevalences of diabetic retinopathy and nephropathy are lower in Korean type 2 diabetic patients with non-alcoholic fatty liver disease. J. Diabetes Investig. 2014, 5, 170-175. [CrossRef]

35. Leite, N.C.; Cardoso, C.R.L.; Salles, G.F. Importance of non-invasive liver fibrosis scores for mortality and complications development in individuals with type 2 diabetes. J. Diabetes Complicat. 2021, 35, 107879. [CrossRef] [PubMed]

36. Lombardi, R.; Airaghi, L.; Targher, G.; Serviddio, G.; Maffi, G.; Mantovani, A.; Maffeis, C.; Colecchia, A.; Villani, R.; Rinaldi, L.; et al. Liver fibrosis by FibroScan $\left({ }^{\circledR}\right)$ independently of established cardiovascular risk parameters associates with macrovascular and microvascular complications in patients with type 2 diabetes. Liver Int. 2020, 40, 347-354. [CrossRef] [PubMed]

37. Lv, W.S.; Sun, R.X.; Gao, Y.Y.; Wen, J.P.; Pan, R.F.; Li, L.; Wang, J.; Xian, Y.X.; Cao, C.X.; Zheng, M. Nonalcoholic fatty liver disease and microvascular complications in type 2 diabetes. World J. Gastroenterol. 2013, 19, 3134-3142. [CrossRef]

38. Mantovani, A.; Rigolon, R.; Mingolla, L.; Pichiri, I.; Cavalieri, V.; Salvotelli, L.; Stoico, V.; Zoppini, G.; Bonora, E.; Targher, G. Nonalcoholic fatty liver disease is associated with an increased prevalence of distal symmetric polyneuropathy in adult patients with type 1 diabetes. J. Diabetes Complicat. 2017, 31, 1021-1026. [CrossRef]

39. Tripolino, C.; Irace, C.; Cutruzzolà, A.; Parise, M.; Barone, M.; Scicchitano, C.; Cortese, C.; Gnasso, A. Hepatic Steatosis Index Is Associated with Type 1 Diabetes Complications. Diabetes Metab. Syndr. Obes. 2019, 12, 2405-2410. [CrossRef]

40. Vendhan, R.; Amutha, A.; Anjana, R.M.; Unnikrishnan, R.; Mohan, V. Clinical profile of nonalcoholic Fatty liver disease among young patients with type 1 diabetes mellitus seen at a diabetes speciality center in India. Endocr. Pract. Off. J. Am. Coll. Endocrinol. Am. Assoc. Clin. Endocrinol. 2014, 20, 1249-1257. [CrossRef]

41. Williams, K.H.; Burns, K.; Constantino, M.; Shackel, N.A.; Prakoso, E.; Wong, J.; Wu, T.; George, J.; McCaughan, G.W.; Twigg, S.M. An association of large-fibre peripheral nerve dysfunction with non-invasive measures of liver fibrosis secondary to non-alcoholic fatty liver disease in diabetes. J. Diabetes Complicat. 2015, 29, 1240-1247. [CrossRef]

42. Yan, L.H.; Mu, B.; Guan, Y.; Liu, X.; Zhao, N.; Pan, D.; Wang, S.Z. Assessment of the relationship between non-alcoholic fatty liver disease and diabetic complications. J. Diabetes Investig. 2016, 7, 889-894. [CrossRef]

43. Zaharia, O.P.; Strassburger, K.; Strom, A.; Bönhof, G.J.; Karusheva, Y.; Antoniou, S.; Bódis, K.; Markgraf, D.F.; Burkart, V.; Müssig, K.; et al. Risk of diabetes-associated diseases in subgroups of patients with recent-onset diabetes: A 5-year follow-up study. Lancet Diabetes Endocrinol. 2019, 7, 684-694. [CrossRef] 
44. Zhao, L.; Ma, J.; Wang, S.; Xie, Y. Relationship between $\beta$-cell function, metabolic control, and microvascular complications in type 2 diabetes mellitus. Diabetes Technol. 2015, 17, 29-34. [CrossRef] [PubMed]

45. Lombardi, R.; Airaghi, L.; Targher, G.; Serviddio, G.; Maffi, G.; Mantovani, A.; Maffeis, C.; Colecchia, A.; Villani, R.; Rinaldi, L.; et al. NAFLD fibrosis score (NFS) can be used in outpatient services to identify chronic vascular complications besides advanced liver fibrosis in type 2 diabetes. J. Diabetes Complicat. 2020, 34, 107684. [CrossRef]

46. Huang, J.; Li, R.; Liu, N.; Yi, N.; Zheng, H.; Zhang, Q.; Zhou, L.; Zhou, L.; Hu, R.; Lu, B. Liver Fibrosis is Independently Associated with Diabetic Peripheral Neuropathy in Type 2 Diabetes Mellitus. J. Diabetes Investig. 2021. [CrossRef] [PubMed]

47. Mikolasevic, I.; Rahelic, D.; Turk-Wensween, T.; Ruzic, A.; Domislovic, V.; Hauser, G.; Matic, T.; Radic-Kristo, D.; Krznaric, Z.; Radic, M.; et al. Significant liver fibrosis, as assessed by fibroscan, is independently associated with chronic vascular complications of type 2 diabetes: A multicenter study. Diabetes Res. Clin. Pract. 2021, 177, 108884. [CrossRef]

48. Casoinic, F.; Sâmpelean, D.; Bădău, C.; Prună, L. Nonalcoholic fatty liver disease-a risk factor for microalbuminuria in type 2 diabetic patients. Rom. J. Intern. Med. 2009, 47, 55-59. [PubMed]

49. Targher, G.; Bertolini, L.; Rodella, S.; Zoppini, G.; Lippi, G.; Day, C.; Muggeo, M. Non-alcoholic fatty liver disease is independently associated with an increased prevalence of chronic kidney disease and proliferative/laser-treated retinopathy in type 2 diabetic patients. Diabetologia 2008, 51, 444-450. [CrossRef]

50. Bugianesi, E.; McCullough, A.J.; Marchesini, G. Insulin resistance: A metabolic pathway to chronic liver disease. Hepatology 2005, 42, 987-1000. [CrossRef]

51. Buzzetti, E.; Pinzani, M.; Tsochatzis, E.A. The multiple-hit pathogenesis of non-alcoholic fatty liver disease (NAFLD). Metab. Clin. Exp. 2016, 65, 1038-1048. [CrossRef] [PubMed]

52. Tilg, H.; Moschen, A.R. IL-1 cytokine family members and NAFLD: Neglected in metabolic liver inflammation. J. Hepatol. 2011, 55, 960-962. [CrossRef] [PubMed]

53. Santi, D.; Spaggiari, G.; Greco, C.; Lazzaretti, C.; Paradiso, E.; Casarini, L.; Potì, F.; Brigante, G.; Simoni, M. The “Hitchhiker's Guide to the Galaxy" of Endothelial Dysfunction Markers in Human Fertility. Int. J. Mol. Sci. 2021, 22, 2584. [CrossRef]

54. Dyson, J.K.; Anstee, Q.M.; McPherson, S. Non-alcoholic fatty liver disease: A practical approach to diagnosis and staging. Front. Gastroenterol. 2014, 5, 211-218. [CrossRef] [PubMed]

55. McPherson, S.; Stewart, S.F.; Henderson, E.; Burt, A.D.; Day, C.P. Simple non-invasive fibrosis scoring systems can reliably exclude advanced fibrosis in patients with non-alcoholic fatty liver disease. Gut 2010, 59, 1265-1269. [CrossRef]

56. Mofrad, P.; Contos, M.J.; Haque, M.; Sargeant, C.; Fisher, R.A.; Luketic, V.A.; Sterling, R.K.; Shiffman, M.L.; Stravitz, R.T.; Sanyal, A.J. Clinical and histologic spectrum of nonalcoholic fatty liver disease associated with normal ALT values. Hepatology 2003, 37, 1286-1292. [CrossRef]

57. Ballestri, S.; Nascimbeni, F.; Lugari, S.; Lonardo, A.; Francica, G. A critical appraisal of the use of ultrasound in hepatic steatosis. Expert Rev. Gastroenterol. Hepatol. 2019, 13, 667-681. [CrossRef] [PubMed]

58. Deprince, A.; Haas, J.T.; Staels, B. Dysregulated lipid metabolism links NAFLD to cardiovascular disease. Mol. Metab. 2020, 42, 101092. [CrossRef] [PubMed]

59. Elosua-Bayés, I.; Beloqui Ruiz, Ó. Association between non alcoholic fatty liver disease, metabolic and vascular risk. Clin. Investig. Arter. 2020, 32, 200-205. [CrossRef]

60. Chen, T.P.; Lai, M.; Lin, W.Y.; Huang, K.C.; Yang, K.C. Metabolic profiles and fibrosis of nonalcoholic fatty liver disease in the elderly: A community-based study. J. Gastroenterol. Hepatol. 2020, 35, 1636-1643. [CrossRef] 